\title{
LEVAMISOLE-INDUCED RESISTANCE TO RAILLIETINA TETRAGONA INFECTION IN YOUNG CHICKS
}

\author{
E. B. ABDELSALAM ${ }^{1}$ and I. E. M. NOURELHUDA ${ }^{2}$ \\ ${ }^{1}$ Department of Veterinary Pathology, ${ }^{2}$ Department of Parasitology, \\ Faculty of Veterinary Science, University of Khartoum, Sudan
}

Received June 2, 1987

A b s t r a c t

A b d e 1 s a 1 a $m$ E.B., I.E.M. $N$ o $u$ r e 1 h u d a: Levamisole-induced Resistance to Raillietina tetragona in Young Chicks. Acta vet. Brno, 57, 1988:141-152.

The repeated pre-treatment with levamisole (L-tetramisole) was found to induce significant resistance to Raillietina tetragona infection in 7 day old chicks. A total of 6 twice weekly oral doses of $2.5 \mathrm{mg} / \mathrm{kg}$ reduced the parasitic burden from $40 \%$ in primarily infected controls $(n=10)$ to $13 \%$ in levamisole-treated chicks $(n=10)$. Resistance to $\underline{R}$. tetragona was also observed in reinfected chicks $(n=9)$ when the intial infection was subsequently treated with niclosamide (Yomesan, $100 \mathrm{mg} / \mathrm{kg}$ ). In this respect, the parasitic burden was reduced to $20 \%$. In addition, a further reduction to $8.8 \%$ of the parasitic burden was obtained in reinfected chicks $(n=9)$ when they were also treated with levamisole at 6 twice weekly doses of $2.5 \mathrm{mg}$ before challenge. The increased resistance of the young chicks to $\underline{R}$. tetragona infection and/or reinfection was attributed to the immunomodulatory action of levamisole.

Raillietina tetragona (cestode), chicks, Levamisole, resistance.

The imidazole compound levamisole (L-tetramisole) has enjoyed considerable interest in veterinary medicine due to its broad spectrum anthelmintic activity and non-specific immunomodulatory effect ( $\mathrm{A}$ b d e 1 s a 1 a m 1986). The latter property was initially discovered by $R$ e $n \circ u \times$ and $\mathrm{R} e \mathrm{n} \circ \mathrm{ux} \quad$ (1971) and further substantiated by numerous investigations and reports ( $\mathrm{J}$ a $\mathrm{n}$ s e $\mathrm{n} \mathrm{1976; \quad S} \mathrm{y} \mathrm{m} \circ \mathrm{e} \mathrm{n}$ and $\mathrm{R}$ o s e $\mathrm{n} \mathrm{th}$ a 1 1977; R e n o u 1978; B r u n e r and M u s o p 1 a t 1980; $\mathrm{Gu}$ o r re ro 1980; $\mathrm{Mu} 1 \mathrm{~g}$ a h y and $\mathrm{Qu}$ i n n 1986). However, the use of levamisole in poultry was still limited to its anthehelmintic efficacy against certain parasitic nematodes including Ascaridia, Capillaria and Heterakis spp. (C 1 a r k s o $\mathrm{n}$ and $\mathrm{B}$ e g 1970; A 1 t a $\mathrm{i} f$ 1972; $\mathrm{P}$ a $\mathrm{n} \mathrm{k}$ a $\mathrm{i} \mathrm{s} \mathrm{h}$ et a1. 1973). The modulatory effect of levamisole upon the avian immune system has not been apparently investigated and the present report, therefore, describes the effect of levamisole pre-treatment on the susceptibility to Raillietina tetragona infection in young chicks. The parasite belongs to the cestode group which does not normally respond to the chemotherapeutic action of the drug. 
Materials and Methods

B $i r$ d $\mathbf{s}$ : Newly-hatched White Leghorn chicks were purchased from commercial farms (Almasara Co. Ltd, Khartoum North) and raised on standard grower diet with free access to water. The chicks were kept for one week before experiments commenced.

D $\quad r \quad$ u $g$ s : Levamisole (Nilverm, ICI solution containing $7.5 \% \mathrm{~W} / \mathrm{V}$ L-tetramisole) Niclosamide (Yomesan $500 \mathrm{mg}$ tablets, Bayer). Levamisole was further diluted to 1 : 10 in water. Niclosamide was also dissolved in water and both drugs were administered orally.

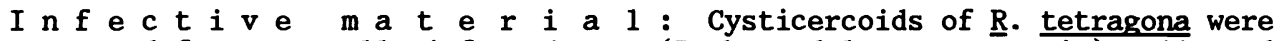
recovered from naturally-infected ants (Pachycondyla sennaarensis) collected from soil in the neighbouring farms. The required number of cysticercoids was suspended in saline and transferred into gelatinous capsule for oral administration.

Ex p e r i m e $\mathrm{n} \mathrm{a} 1$ d e $s$ i $g$ n : Two complementary experiments were performed on the effect of levamisole against primary infection and reinfection with the homologous cestode.

$\mathrm{E} \times \mathrm{p}$ e $\mathrm{r} \mathrm{i}$ e $\mathrm{n} \mathrm{t} \quad 1$ : (Primary infection)

Twenty chicks were divided into two equal groups (A \& B). The first group (A) was pre-treated with $2.5 \mathrm{mg} / \mathrm{kg}$ levamisole twice weekly for three weeks. Group B was left without treatment for the same period of time. Both groups were then infected with $\underline{R}$. tetragona (15 cysticercoids/chick)and killed two weeks post infection (see Table 1).

Table 1

Experimental design and results of experiment I (Primary infection)

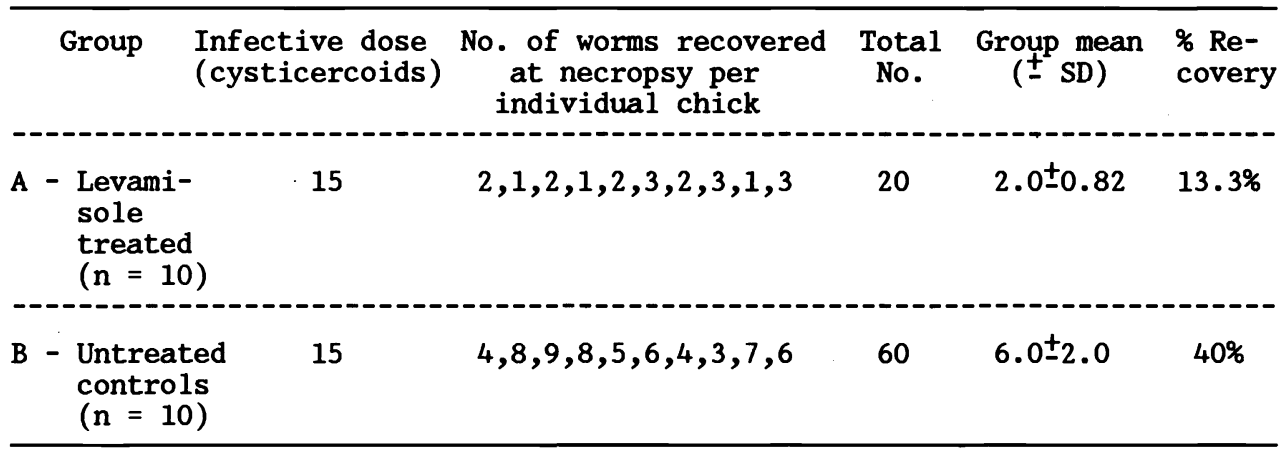

Expe $r$ i m e $\mathrm{nt} 2$ : (Reinfection)

Three equal groups of chicks $\left(A_{1}, B_{1} \& B_{2}\right)$ were used. Each group was composed of 9 chicks of the same age (7-day old). Groups $B_{1}$ and $B_{2}$ were initially infected with 20 cysticercoids per chick and subsequently treated with niclosamide $(100 \mathrm{mg} / \mathrm{kg})$ a week after. Both groups were then reinfected with the same number of cysticercoids and killed after another two weeks (Table 2). However, group $B_{2}$ chicks were first pre-treated with levamisole $(2.5 \mathrm{mg} / \mathrm{kg}$ twice weekly) for 3 weeks before reinfection. On the other hand, group $A_{1}$ chicks were used as primarily infected controls (i.e infected with $20^{1}$ cysticercoids each and killed two weeks post - infection for comparison). 
Table 2

Experimental design and results of experiment 2 (Reinfection)

\begin{tabular}{|c|c|c|c|c|c|c|}
\hline Group & $\begin{array}{l}\text { Infective } \\
\text { (cysticer } \\
\text { Primary Ch }\end{array}$ & $\begin{array}{l}\text { dose } \\
\text { oids) } \\
\text { llenge }\end{array}$ & $\begin{array}{l}\text { No. of worms recovered } \\
\text { at necropsy per } \\
\text { individual chick }\end{array}$ & $\begin{array}{l}\text { Total } \\
\text { No. }\end{array}$ & $\begin{array}{c}\text { Group mean } \\
( \pm \mathrm{SD})\end{array}$ & $\begin{array}{l}\text { \% Re- } \\
\text { covery }\end{array}$ \\
\hline $\begin{aligned} A_{1}- & \text { Prima- } \\
& \text { rily } \\
& \text { infec- } \\
& \text { ted } \\
& (n=9)\end{aligned}$ & 20 & 0 & $12,9,11,9,7,8,12,10,8$ & 86 & $9.6 \pm 1.81$ & $47.8 \%$ \\
\hline $\begin{array}{c}B_{1}-\begin{array}{l}\text { Reinfec } \\
\text { ted } \\
(n=9)\end{array} \\
\end{array}$ & $\begin{array}{l}c-\quad 20 \\
\text { (treated } \\
\text { with } \\
\text { niclos- } \\
\text { amide) }\end{array}$ & 20 & $4,6,2,4,3,5,4,5,3$ & 36 & $4.0 \pm 1.22$ & $20 \%$ \\
\hline $\begin{array}{c}\mathrm{B}_{2}-\text { Rein- } \\
\text { fected } \\
\text { /leva- } \\
\text { misole } \\
\text { treated } \\
(\mathrm{n}=9)\end{array}$ & $\begin{array}{l}\quad 20 \\
\text { (treated } \\
\text { with } \\
\text { niclos- } \\
\text { amide) }\end{array}$ & 20 & $2,1,1,2,3,1,1,3,2$ & 16 & $1.8 \pm 0.83$ & $8.8 \%$ \\
\hline
\end{tabular}

Wor $\mathrm{m} \quad \mathrm{r}$ e c o ve $\mathrm{r} y$

The whole intestines were immediately removed at necropsy and opened into plastic dishes containing normal saline. The content was evacuated and the recovered worms were collected and preserved in Roudabush solution. They were then identified under light microscope an: counted individually. Student's t-test was employed for the statistical evaluation of the results.

\section{Results}

The results of tapeworm recovery in primary infection and reinfection with $\underline{R}$. tetragona in chicks are also shown in tables 1 and 2 .

P r i m a y i n e c t i o n (Table 1):

The mean parasitic burden in levamisole-treated chicks (group A) was significantly lower $(P<0.001)$ than in untreated controls (group B). The mean percentage tapeworm recovery was reduced from $40 \%$ in the control group to $13 \%$ in levamisole treated chicks.

$\mathrm{R}$ e i n e c $\mathrm{t}$ i o $\mathrm{n}$ (Table 2):

The total worm burden in the reinfected groups $\left(B_{1}\right.$ and $\left.\mathrm{B}_{2}\right)$ was significantly lower $(\mathrm{P}<0.001)$ than in primarily infected chicks (group $A_{1}$ ). The overall percentage tapeworm 
recovery was reduced to $20 \%$ in the reinfected chicks (group $B_{1}$ ) without levamisole treatment. However, a further reduction to $8.8 \%$ of the overall percentage tapeworm recovery was obtained by levamisole treatment in reinfected chicks (group $\mathrm{B}_{2}$ ).

The results of the present work have generally indicated that the pretreatment of young chicks with repeated doses of levamisole $(2.5 \mathrm{mg} / \mathrm{kg}$ twice weekly for three weeks) increased their resistance to $\underline{R}$. tetragona infection as judged by the significant reduction of worm recovery (Table 1 ). The result was probably due the immunomodulatory action of levamisole, since the drug was not found to have any anthelmintic efficacy against tapeworms ( $T h$ i e $n p o n t$ et al. 1966; J a $n$ s $s$ e $n$ 1976). Although the modulatory effect of levamisole upon the mammalian immune system is now well recognized ( $M$ u $l$ e a $h y$ and $Q u$ i $n$ 1986), however, the exact mechanisms by which the drug can exert its immunological effects are not fully understood. Nevertheless, the drug was suggested to enhance the lymphocyte proliferative responses, increase lymphokin production and promote macrophage function (phagocytosis) (A 1 - I b $\mathrm{r}$ a $\mathrm{h} \mathrm{i} \mathrm{m} \mathrm{et} \mathrm{al.} \mathrm{1977).} \mathrm{In} \mathrm{addition,} \mathrm{the} \mathrm{drug} \mathrm{was} \mathrm{found}$ to be more effective in young hosts ( $J$ a $n s$ e $n$ 1976) and in those with hypofunctional $\mathrm{T}$ - lymphocytes ( $G \mathrm{u}$ e $r \mathrm{r}$ o $\mathrm{r}$ o 1980). In the present report, the chicks were used as young as 7-day old and that would probably account for the relative success of the drug in inducing significant immune protection against the parasite ( $\underline{R}$. tetragona).

Acquired resistance to homologous reinfection with cestode parasites has been previously reported ( $\mathrm{H} \mathrm{e}$ a $\mathrm{t} \mathrm{h}$ et al. 1979). In the present work, a significant resistance to reinfection with $\mathrm{R}$. tetragona was also observed in young chicks (Table 2). The results, therefore, indicate that chicks are capable of developing acquired resistance to homologous reinfection with the cestode parasites. Such resistance was probably due to the antigenic stimulation caused by the destruction and disintegration of the dead parasite of the previous infection as a result of niclosamide treatment. Resistance to reinfection was also enhanced by levamisole pre-treatment (Table 2).

It is finally concluded that the routine use of levamisole in poultry management is highly benificial in terms of its broad-spectrum anthelmintic activity and non-specific immunomodulation. 
Acknowledgement

This work was supported by a grant from the Faculty Research Board, University of Khartoum. We are grateful to Dr. S. Alowni and Professor T. Hassan for their help and interest.

Levamisolem indukovaná resistence

$\mathrm{k}$ infekci Raillietina tetragona u kur̆at

Opakovaná premedikace levamisolem (L-tetramisole) vedle k signifikantní resistenci vůči infekci Raillietina tetragoną u 7 denních kuřat. Celkem 6 orálních dávek po $2,5 \mathrm{mg} . \mathrm{kg}$ zredukovalo 40\%ní parazitární invazi u primárně infikovaných kontrol $(\mathrm{n}=10)$ na $13 \% \mathrm{u}$ kur̆at ošetřených levamisolem. Resistence vůči $\mathrm{R}$. tetragona byla také pozorována $\mathrm{u}$ reinfikovaných kuřat $(n=9)$, když byla počáteční infekce léčena niclosamidem (Yomesan, $100 \mathrm{mg} \cdot \mathrm{kg}^{-1}$ ). V tomto případě byla parazitární invaze zredukována na $20 \%$. Další redukce na $8,8 \%$ nastala $u$ reinfikovaných kuřat $(n=9)$, která byla také ošetřena levamisolem za použití 6 dávek po $2,5 \mathrm{mg} 2 \times$ týdně před čelenží. Zvýšená resistence kuřat $\mathrm{k}$ infekci $\underline{\mathrm{R}}$. tetragona a reinfekci je přisuzována imunomodulačnímu účinku levamisolu.

Индуцированная левамизолом резистентность к инфекции Raillietina tetragona $\mathrm{Y}$ цыплят

Повторная премедикация левамизолом (L-tetramisoleä вылилась в значимую резистентность $К$ инфекции

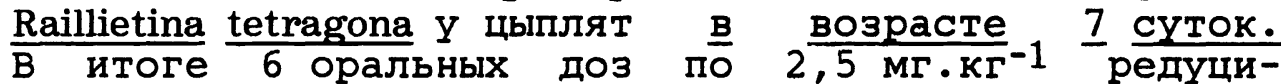
ровало 40\% паразитарную инвазию Y первично инфицированных контрольных групп (н=10) в случае $13 \%$ цыплят, принимающих левамизол. Резистентность K R. tetragona наблюдали также $Y$ реинфицированных цыплят $(\mathrm{n}=9)$, когда начальную инфекцию лечили никлосамидом' (емесан, $100 \mathrm{M \Gamma .KГ}^{-1}$ ). В данном слүчае паразитарную инвазию редуцировали до 20\%. Последующая редукция до $8,8 \%$ имела место $y$ повторно инфицированных цыплят $(\mathrm{n}=9)$, принимающих левамизол 
в 6 дозах по 2,5 мг два раза в неделю перед челенжированием . Повышенная резистентность цыплят к инФекции $\mathrm{R}$. tetragona и реинфекции связывается с иммуномодуляционным воздействием левамизола.

\section{References}

ABDELSALAM, E.B.: The effect of levamisole (L. tetramisole) in domestic animals. Acta Vet. (Beograd i, 36, 1986: 23-30.

A1-IBRAHIM, M.S. - HOLZMAN, R.S. - LAURENCE, H.S.: Concentration of levamisole required for enhanced proliferation of human lymphocytes and phagocytosis by macrophages. J. Infect. Dis., 135, 1977: 517-523.

ALTAIF, K.I.: Comparative evaluation of efficacies of ditetramisole and piperazine against Ascardia galli in chickens. Am. J. Vet., Res., 33, 1972: 1547.

BRUNNER, C.J. - MUSCOPLAT, C.C.: Immunomodulatory effect of levamisole. J.A.V.M.A., 176, 1980: 1159-1162.

CLARKSON, M.K.: The anthelmintic activity of L. tetramisole against Ascaridia galli and Capillaria obsignata in the fow1. Vet. Rec., 86, 1970: 652 .

GUORRERO, J.: Parasite host interactions relative to levamisole. J.A.V.M.A., 176, 1980: 1163-1165.

HEATH, D.D. - LAWRENCE, S.B. - YOUNG, W.K.: Gross protection between the cysts of Echinococcus granulosus, Taenia hydatigena and $\mathrm{T}$. ovis in Lambs. Res. Vet. Sci., 27, 1979: 210-212.

JANSSEN, P.A.J.: The levamisole story. Prog. Drug. Res., 20, 1976: 347-383.

MULGAHY, C. - QUINN, P.J.: A review of immunomodulators and their application in veterinary medicine. J. Vet. Pharmacol. Therap., 9, 1986: 119-139.

PANKAVICH, J.A. - POESCHEL, G.P. - SHOR, A.: Evaluation of levamisole against experimental infections of Ascaridia, Heterakis and Capillaria spp. in chickens, Am. J. Vet. Res., 34, 1973: 501.

RENOUX, G.: Modulation of immunity by levamisole. Pharmacol. Therap., 2, 1978: $397-423$.

RENOUX, G. - RENOUX, M.: Effect immunostimulant d un Imidothiazole dans $\mathrm{L}$ 'immunisation des souris contre $\mathrm{L}^{\prime}$ infection par Brucella abortus. C.R. Acad. Sci., 272, 1971: 349-350.

SYMOENS, J. - ROSENTHAL, M.: Levamisole in the modulation of the immune response: The current experimental and clinical state. J. Retic. Soc., 25, 1977: 125-221.

THIENPONT, D. - VANPARIJS, O.F.J. - RAEYMAEKERS, A.H.M. - ALLEWIJN, F.T.N. - MARSBOOM, R.P.H. - NIEMEGGEERS, C.J.E. - SCHELLEKENS, K.H.L. - JANSSEN, P.A.J.: Tetramisole (R829a) A new potent broad spectrum anthelmintic, Nature, 209, 1966: 1084-1086. 